\section{Comparison of Asparagus Cultivars during Storage}

\author{
P. Perkins-Veazie', J.K. Collins', \\ T.G. McCollum ${ }^{2}$, and J. Motes ${ }^{3}$
}

Additional index words. Asparagus officinalis, postharvest

Summary. Four asparagus (Asparagus officinalis L.) cultivars, UC 157, Syn 4-56, Mary Washington, and Viking $\mathrm{KB3}$, were stored at $2 \mathrm{C}$, and their quality was evaluated during 3 weeks of storage, There were no cultivar differences in respiration, weight gain, or soluble solids concentration initially or after storage. After 3 weeks of storage, the cultivars UC and S4 were more vividly green and less seedy than MW or VK, but UC exhibited slight to moderate chilling injury. Spears of S4 and VK had better overall appearance than MW or U C.

$\mathrm{G}$ ood-quality asparagus must be clean, crisp, and have attractive color and tightly closed tips. Because horticulturally mature asparagus consist of vegetative tissue harvested during a period of rapid growth, the spears have high respiration rates, are susceptible to high weight loss, and can quickly toughen due to stem lignification. Asparagus must be cooled immediately after harvest, stored between 0 and $2 \mathrm{C}$, and marketed within 3 weeks to prevent these problems (Hardenburg et al., 1986). Greater weight loss and decay occur at higher storage temperatures, while chilling injury can occur when aspara-

${ }^{I}$ U.S. Department of Agriculture, Agricultural Research Service, South Central Agricultural Research Laboratory, Lane, OK 74555.

${ }^{2}$ U.S. Department of Agriculture, Agricultural Research Service, United States Horticulture Research Laboratory, Orlando, FL 32803.

${ }^{3}$ Department of Horticulture, Oklahoma State University, Stillwater, OK 74074.

Mention of trademark, proprietary product, or vendor does not constitute a guarantee or warranty of the product by the USDA and does not imply its approval to the exclusion of other products of vendors that may also be suitable. gus is held at temperatures below $2 \mathrm{C}$ for more than 10 days (Lipton, 1958).

Hybrid selections are being planted in areas new to asparagus production or used to replant established commercial sites. A Fusarium heattolerant cultivar, UC-157, is being planted in many southern U.S. states. 'Syn $4-56$ ' is a widely adapted hybrid mixture containing the all-male 'Jersey Giant' and is recommended for its productivity and Fusarium tolerance (Peirce, 1987). This study evaluated the postharvest quality of stored hybrid and open-pollinated asparagus cultivars.

\section{Materials and methods}

Asparagus cultivars Syn 4-56 (S4), Viking KB3 (VK), Mary Washington (MW), and UC 157 (UC) were harvested from a 4-year-old asparagus planting at Lane, Okla. Spears of each cultivar were harvested at four dates during a 6-week period from April through May (average air temperatures $21 \pm 5 \mathrm{C}$ ). Four replications of 10 spears were used for each cultivar and harvest date. Spears of marketable diameter $(1.2$ to $1.7 \mathrm{~cm})$ were cut at ground level and then trimmed to a length of 20 to $22 \mathrm{~cm}$. The asparagus was rinsed in $15 \mathrm{C}$ water containing 100 to $200 \mathrm{mg}$ chlorine/liter.

Horizontal lines $2.5 \mathrm{~cm}$ apart were drawn with a felt tip marker on spears at tip, mid, and bottom $(1 \mathrm{~cm}$ from tip and bottom) locations. Weekly color readings were taken between these lines using a Minolta CR-200 tristimulus chromameter (Minolta, Ramsey, N.J,) with a CIELAB, D65 Illuminant (d/0 illuminating/viewing geometry) with a $8-\mathrm{mm}$ aperture and standardized with a white reference plate $(\mathrm{L}=$ 97.7, $\mathrm{a}=0.48, \mathrm{~b}=2.23)$. $\mathrm{Hue}^{\circ}$, a measure of color, and chroma, a measure of color intensity, were calculated (Hung, 1990).

Spears were placed upright on moistened \#3 Whatman filter paper pads in 3.8-liter glass jars. The asparagus was stored at $2 \pm 0.5 \mathrm{C}, 95 \% \mathrm{RH}$ for 3 weeks. Between measurements, jars were covered with perforated plastic bags to prevent excessive air circulation over the spears. Weights were taken weekly, and respiration was measured in a closed system by injecting 1$\mathrm{ml}$ gas samples into a Hewlett-Packard 5890 gas chromatograph equipped with a thermal conductivity detector and a 2.1-m, 0.3-cm-diameter stain- less steel column packed with Poropak N 80/100 mesh.

For initial and final soluble solids concentration (SSC), five spears/replication were ground with an equivalent water weight in a Waring blender for $5 \mathrm{~min}$, the macerate was strained through three layers of cheesecloth, and soluble solids concentration in the strained juice was measured using an Abbe-3L refractometer.

Spears were evaluated weekly for the development of decay, expansion of the cladophylls ("seediness"), turgidity, and overall appearance (a combination of the three ratings plus visual color, appearance, and chilling injury). A subjective rating scale of 9 (good) to 1 (poor) was used. Data were analyzed by analysis of variance (ANOVA) and means separated using LSD) (SAS Institute, 1988).

\section{Results and discussion}

As has been reported by others (Hardenburg et al., 1986; Scott and Kramer, 1949), asparagus had gains in fresh weight during storage when held on moist filter paper. No significant differences were found among the four cultivars or harvest dates in total percentage of weight gain. After 2 days, asparagus had gained about 3\% weight; after 3 weeks of storage, weight gain had increased to $\approx 7 \%$, similar to that reported by Scott and Kramer (1949). Spears of all the cultivars elongated $\approx 1$ $\mathrm{cm}$ during storage due to contact with moistened pads (Morris and Watada 1960).

The respiration rates of the four asparagus cultivars were high during the first week of storage $(66 \pm 7 \mathrm{ml}$ $\mathrm{CO}_{2} / \mathrm{kg}$ per h) and then decreased to $20 \pm 3 \mathrm{ml} \mathrm{CO}_{2} / \mathrm{kg}$ per $\mathrm{h}$ during the remaining 2 weeks of storage. This trend is similar to that established by others (King et al. 1988; Saltveit and Kasmire, 1985).

Soluble solids concentration were not different among cultivars and did not change after 3 weeks in storage $(5.4 \% \pm 0.3 \%)$; asparagus from early harvests were slightly lower in SSC $(4.9 \% \mathrm{~s} \pm 0.1 \%)$.

Harvest date and length of storage did not affect color of asparagus at any stem location. Tip L value (38) and hue ${ }^{\circ}$ (92) were not different among cultivars. Tips of the cultivar UC had the highest chroma (more vivid color), S4 the lowest, and the others were intermediate (Table 1). Hue ${ }^{\circ}$ and chroma 
Table 1 . Color differences in asparagus stems at tip and base locations for the cultivars Mary Washington (MW), Viking KB3 (VK), Syn 4-56 (S4), and UC 157 (UC).

\begin{tabular}{lccc}
\hline & \multicolumn{2}{c}{ Chroma } & Hue $^{\circ}$ \\
\cline { 2 - 3 } Cultivar & Tip & Base & \\
\hline MW & $8.6 \mathrm{~b}^{7}$ & $20.8 \mathrm{a}$ & $98.6 \mathrm{a}$ \\
VK & $8.0 \mathrm{~b}$ & $22.2 \mathrm{~b}$ & $102.5 \mathrm{ab}$ \\
S4 & $5.1 \mathrm{a}$ & $20.1 \mathrm{a}$ & $99.6 \mathrm{a}$ \\
UC & $12.0 \mathrm{c}$ & $24.2 \mathrm{c}$ & $108.3 \mathrm{~b}$ \\
\hline
\end{tabular}

${ }^{z}$ Means in a column followed by the same letter are not significantly different ( $P \leq 0.05 ; L S D)$.

at the mid-stem locations, and $\mathrm{L}$ value at the base of the stems, were not different among cultivars $(114,23$, and 53, respectively). Hue and chroma at the base of UC and VK stems were higher than those of other cultivars, indicating a more vivid green color compared to MW or S4.

After 3 weeks of storage, spears of all cultivars and harvest dates had ratings $>5$ (Table 2). However, physical characteristics differed among cultivars. Spear tips of S4 and UC appeared less "seedy" than those of the other two cultivars. Spears of UC and MW had more decay than those of S4 or VK. Although none of the cultivars became unacceptably limber, MW spears were slightly more flaccid than those of other cultivars. Spears of S4 and VK had the best overall appearance. This is similar to the results of King et al. (1986), who reported that

Table 2. Subjective mean ratings for overall appearance, seediness, decay, and limberness of cultivars Mary Washington (MW), Viking KB3 (VK), Syn 4-56 (S4), and UC 157 (UC) after 3 weeks of storage at 2C. Overall appearance was rated on a scale of 9 (good) to 1 (poor); expansion of cladophyll/seediness of 9 (not expanded or not seedy) to 1 (fully expanded or very seedy); decay of 9 (no decay) to 1 (extensive decay); limberness of 9 (rigid) to I (very flaccid).

Overall

Cultivar appearance Seediness Decay Limbernes

$\begin{array}{llllll}\text { MW } & 5.5 b^{2} & 5.7 b & 5.9 b & 6.4 b\end{array}$

VK $\quad \begin{array}{lllll}5.8 \mathrm{a} & 6.0 \mathrm{~b} & 6.2 \mathrm{a} & 6.8 \mathrm{a}\end{array}$

S4 $\quad 6.0 \mathrm{a} \quad 6.4 \mathrm{a} \quad 6.3 \mathrm{a} \quad 7.0 \mathrm{a}$

UC $\quad 5.4 \mathrm{~b} \quad 6.6 \mathrm{a} \quad 5.9 \mathrm{~b} \quad 6.7 \mathrm{ab}$

$\overline{{ }^{2} \text { Means in a column followed by the same letter are }}$ not significantly different $(\mathrm{P} \leq 0.05 ; \mathrm{LSD})$.
New Zealand-grown S4 had a longer shelf life than MW.

Although not generally regarded as a chilling-sensitive crop, asparagus will develop symptoms of chilling injury if held below $1 \mathrm{C}$ for more than 10 days (Hardenburg et al., 1986). We observed symptoms of chilling injury in this experiment, expressed as flaccidity and darkening of tips to a graygreen color after 3 weeks of storage, similar to reports of Lipton (1990). Pitting and water-soaked lesions were also present on 'UC 157'; these symptoms have not been reported previously on asparagus. Slight chilling injury was noted on a few S4 spears, but none was observed on MW or VK spears. Forty percent of the UC spears were slightly to moderately affected by chilling (data not shown) for all harvest dates. Klieber and Wills (1992) reported chilling injury on $\mathrm{New}$ Zealand-grown UC spears stored at $1.5 \mathrm{C}$, whereas Hernandez-Rivera et al. (1992) reported no chilling injury when California-grown UC was stored 24 days at $0.5 \mathrm{C}$. The different expression of CI in these studies may result from diverse environmental conditions among production locations.

The availability of new hybrid asparagus cultivars has led to inquiries about their suitability for regional production. Most postharvest work has been done on open-pollinated cultivars. Regional production data indicate that the hybrid S4 has twice the yield $\left(2000 \mathrm{~kg} \cdot \mathrm{ha}^{-1}\right)$ compared to MW, $\mathrm{VK}$, or UC cultivars $\left(1000 \mathrm{~kg} \cdot \mathrm{ha}^{-1}\right)$ (Motes, 1987). However, when harvest temperatures were above $30 \mathrm{C}, \mathrm{S} 4$ tended to fern out sooner and did not always reach the standard marketable length of $23 \mathrm{~cm}$ with tight heads (J. Motes, personal observation). Additionally, the appearance of chilling injury on the hybrid cultivars UC and S4 indicate a temperature sensitivity. Overall, in asparagus stored up to 3 weeks, the S4 and VK cultivars had better appearance than did UC or MW. Our results indicate that postharvest investigations as well as production trials are important when recommending new asparagus cultivars.

\section{Literature Cited}

Hardenburg, R.E., A.E. Watada and C.Y. Wang 1986. The commercial storage of fruits, vegetables, and florist and nursery stocks. USDA Hdbk. 66:13, 52-53.

Hernandez-Rivera, L., R. Mullen, and M. Cantwell. 1992. Textural changes of asparagus in relation to delays in cooling and storage conditions. HortTechnology 2: 378-381.

Hung, Y.C. 1990. Effect of curvature and surface area on colorimeter readings-a model study. J. Food Qual. 13:259-269.

King, G.A., K.G. Henderson, E.M. O'Donoghue, W. Martin, and R.E. Lill. 1988. Flavour and metabolic changes in asparagus during storage. Scientia Hort. 36:183-190

King, G.A., K.G. Henderson, and R.E. Lill. 1986. Asparagus: Effect of controlled atmosphere storage on shelf-life of four cultivars. N.Z. J. Expt. Agr. 14:421-424.

Klieber, A. and R.B.H. Wills. 1992. Optimisation ofstorage conditions for 'UC 157' asparagus. Austral. J. Expt. Agr. 32:529-534.

Lipton, W. 1958. Effect of temperature on asparagus quality. Proc. Conf. Transport. Perishables. Univ. of Calif. 3-5 Feb. p. 147-151.

Lipton, W.J. 1990. Postharvest biology of fresh asparagus. Hort. Rev. 12:69-155.

Morris, L.L. and A.E. Watada. 1960. Elongation and bending of asparagus spears. Calif. Agr. 14:15.

Motes, J. 1987. Asparagus variety trials. 1987 Vegetable Trial Rpt. Okla. State Univ. Hort 88-1.

Peirce, L. 1987. Perennial crops. Vegetables. Wiley, New York. p. 173-184.

Saltveit, M.E. and R.F. Kasmire. 1985. Changes in respiration and composition of different length asparagus spears during storage. HortScience 20:1114-1116.

SAS Institute. 1988. SAS procedures guide. SAS Institute, Inc., Cary, N.C.

Scott, L.E. and A. Kramer. 1949. Physiological changes in asparagus after harvest. Proc. Amer. Soc. Hort. Sci. 54:357-366. 